\title{
Dissolution of lead matte and copper slag upon exposure to rhizosphere-like conditions
}

\author{
Anna Potysz ${ }^{1}$ and Jakub Kierczak ${ }^{1}$ \\ 'University of Wroclaw, Institute of Geological Sciences, Cybulskiego 32, 50-205 Wroclaw
}

Record

Laboratory leaching test simulating rhizosphere weathering records a high release of metals from sulphidic lead matte and glassy copper slag.

Abstract

Metallurgical wastes displaying various chemical and mineralogical properties may reveal different behaviour under exposure to weathering conditions. The latter impact the stability of the wastes, which often results in metal release and subsequent pollution problems. The aim of this study was to compare the weathering of two types of metallurgical wastes (i.e., copper slag and lead matte) exposed to artificial root exudates organic solutions and demineralized water. The results of experimental weathering demonstrated that the extent of waste dissolution depends on the composition of weathering solution as well as on the waste properties. Artificial root exudates rich in organic acids were found to enhance elements release from sulphide rich lead matte and copper glassy slag relative to demineralized water control. The release of elements from the wastes exposed to artificial root exudates for 7 weeks reached $17.8 \%$ of $\mathrm{Pb}$ and $4.97 \%$ of $\mathrm{Cu}$, for lead matte and granulated slag respectively. The most leachable elements may result from the dissolution of intermetallic phases hosting these elements. The fraction size ranging from $0.25-0.5 \mathrm{~mm}$ to $1-2 \mathrm{~mm}$ was found to be a minor factor in elements release under studied conditions.

\section{Introduction}

Metal mining and processing produce huge amounts of solid wastes such as slags, mattes, ashes, and waste rocks (Piatak et al. 2004). Former waste management did not carefully consider the properties of metallurgical wastes and the latter have often been disposed of without appropriate environmental attendance (Potysz et al. 2015). As a result, the historical landfill sites are characterized by the presence of waste dumps, or in some cases, the random dispersal of wastes around the disposal area (Kierczak et al. 2013). The complete lack of waste isolation from the surrounding environment has enabled the weathering processes to go on for a long period of time (Parsons et al. 2001; Kierczak et al. 2013; Tyszka et al. 2014). The extent and dynamic of weathering in the field depends on broad range of geochemical conditions. The interactions of environmental agents including organic matter, root exudates, microorganisms, and so on with disposed wastes may affect their geochemical stability (Potysz et al. 2016a; Potysz et al. 2016b; Potysz et al. 2017). However, individual phase components (synthetic equivalents of minerals) of the metallurgical waste exhibit different susceptibility to weathering (Ettler et al., 2002; Ettler et al. 2009, Piatak and Seal, 2010; Piatak et al. 2015; Potysz et al. 2015; Potysz et al. 2017). As a result of the work of various deteriorative agents, harmful elements (e.g., metallic
Keywords

Lead matte, copper slag, weathering, root exudates, metal release

Received: 24.07.2017 Accepted: 16.11.2017

contaminants) originally present in the waste may be released in high quantities. The metal-rich effluent originating from the waste weathering can reach the soil and migrate towards other environmental components including sediments, ground and surface waters (Tiller, 1989; Gee et al., 1997; Manz and Castro 1997; Hudson-Edwards et al., 1999; Lottermosser 2002; Ettler et al., 2004; Piatak and Seal 2010; Lottermoser, 2010 Kierczak et al. 2013; Ettler and Johan, 2014; Potysz et al., 2016a; Jarosíkova et al., 2017). The presence of excessive content of toxic elements in the environment is undesirable, because the retention by biota and flora makes metals more accessible for higher levels of food chain and may lead to possible intake by humans (Bortey-Sam et al., 2015). Therefore, the geochemical stability of the metallurgical wastes disposed at former disposal sites has received relevant attention of scientific communities (e.g., Ettler et al. 2003; Ettler and Johan 2014, Tyszka et al. 2014; Kierczak et al. 2013; Potysz et al. 2016c).

The evaluation of factors influencing the waste stability under conditions corresponding to realistic scenarios is of critical need not only for assessing the environmental risk, but also for developing suitable remediation strategies. Thus, the reliable verification methodologies predicting the behaviour of wastes have to be carried out (Schmukat et al. 2012). Laboratory leaching tests are useful screening methods for the preliminary assessment of 
Table 1. Chemical and phase composition of metallurgical waste (Potysz et al. 2016c).

\begin{tabular}{c|c|c}
\hline \multicolumn{2}{|c}{ Metallurgical waste } \\
\hline Element [wt.\%] & Lead matte (LM) & Copper slag (GS) \\
\hline $\mathbf{S i}$ & 1.9 & 15.2 \\
\hline $\mathbf{F e}$ & 30.4 & 11.5 \\
\hline $\mathbf{C u}$ & 1.1 & 1.1 \\
\hline $\mathbf{Z n}$ & 7.6 & 0.8 \\
\hline $\mathbf{P b}$ & 2.6 & 2.1 \\
\hline Phases & & glass \\
\hline Silicates & $\begin{array}{c}\text { glass * } \\
\text { fayalite }\end{array}$ \\
\hline Metal-bearing phases & $\begin{array}{c}\text { sphalerite ** } \\
\text { intermetallic Pb }\end{array}$ \\
\hline
\end{tabular}

* volumetrically minor, ${ }^{* *}$ volumetrically major

environmental risk associated with metal release from the wastes (Piatak et al., 2015; Potysz et al., 2015). The placement of wastes on the ground surface without isolating physical barriers enables their direct contact with soil. It is important to note that metal solubility and mobility in the environment is governed by dissolved organic carbon (DOC), whose content varies in different soil types and horizons (Jobbágy and Jackson 2000). Dissolved organic carbon is mainly supplied through root exudation, microbial excretion and decaying biomass (Jones, 1998; Wu et al., 2002). Therefore, the DOC content in rhizosphere soil fraction is higher as compared to other soil layers (Kay 1998). Thus, the research on the processes that may go on at slag/soil interface taking into account the variability of DOC concentration is interesting to undertake.

The main objective of this study was to evaluate the stability of two different metallurgical wastes (i.e., copper slag and lead matte) under exposure to artificial root exudates reflecting rhizosphere-like weathering scenario. The effect of artificial root exudates concentration (DOC $6 \mathrm{mg} / \mathrm{L}-600 \mathrm{mg} / \mathrm{L}$ ) and the waste particle size (0.25-2 $\mathrm{mm}$ ) were evaluated. The experiments lasted for 7 days. Furthermore, a long-term comparison was made between organic conditions (artificial root exudates DOC $60 \mathrm{mg} / \mathrm{L}$ ) and neutral (demineralized water) inorganic conditions on the wastes dissolution in a time frame of 7 weeks.

\section{2. MATERIALS AND METHODS}

\subsection{Metallurgical waste characterization}

Two types of metallurgical wastes displaying different chemical and mineral phase compositions were chosen for this study (Table 1, Potysz et al. 2016c). The lead matte (LM) corresponds to sulphide-rich metallurgical waste originating from the lead recovery process (Potysz et al. 2016c), whereas granulated slag (GS) is an amorphous glassy material resulting from copper processing (Potysz et al. 2016c). The reason for choice of two wastes differing in composition was to represent various weathering scenarios. It is known that the metallurgical wastes disposed in different locations reveal compositional variability (Piatak et al. 2015, Potysz et al. 2015). Thus, the comparison made between silicate-rich and sulphidic-rich waste materials has implications for environmental risk assessment in the areas where similarly composed wastes are disposed of.

\subsection{Weathering solutions}

The composition of artificial root exudates (ARE) solution was modified after Baudoin et al. (2003). Artificial root exudates stock solution was prepared by dissolving glucose (18.4 mM), fructose (18.4 mM), sucrose $(9.2 \mathrm{mM})$, citric acid $(9.2 \mathrm{mM})$, lactic acid (18.4 $\mathrm{mM}$ ) and succinic acid (13.8 $\mathrm{mM})$ in $1 \mathrm{~L}$ of demineralized water to receive dissolved organic carbon (DOC) concentration of $6000 \mathrm{mg} / \mathrm{L}$. Then, the leaching solutions with different ARE concentrations were prepared by 10,100 and 1000 times dilutions of the above-mentioned stock solution in acidified demineralized water to receive 600,60 and $6 \mathrm{mg} / \mathrm{L}$ DOC concentration in ARE solution. Initial $\mathrm{pH}$ of each solution was fixed at 3.5. The content of organic acids (hence, DOC) in the environment depends on plant species, developmental stage, root density, nutrient availability and the presence of contaminants (Anderson et al. 1993; Sandnes et al. 2005). Therefore, ARE having different DOC content were used for the experiments. These solutions simulate rhizosphere conditions at which metallurgical waste may be weathered.

\subsection{Leaching experiments}

The first leaching experiment addressed the impact of organic acid rich root exudates (ARE $\mathrm{pH} \mathrm{t}_{0}=3.5$ ) with different DOC con- 
centrations ( 6,60 and $600 \mathrm{mg} / \mathrm{L})$ on the wastes dissolution. Experimental leaching controls were done with demineralized water (DW pH $\mathrm{t}_{0}=3.5$ ), acidified using $0.01 \mathrm{M}$ succinic acid. The waste dissolution in demineralized water (DW) has been presented as the lowest-risk weathering scenario. The second experiment evaluated the effect of the waste particle size on dissolution intensity under exposure to ARE (60 mg/L DOC concentration). The ARE 60 solution was chosen, because $60 \mathrm{mg} / \mathrm{L} \mathrm{DOC}$ content is considered to be the most realistic to occur in natural soil environment. These leaching experiments lasted 7 days.

Long-term (7 weeks long) experimental comparison was made on metallurgical waste dissolution in organic ARE (60 mg/L DOC) solution and demineralized water (DW). The importance of longterm studies lies in the observation of evolution of leaching rates. That in turn enables to predict how the wastes may behave in the real disposal system and therefore assess possible environmental risk.

The experiments addressing the effect of ARE concentration and long-term experiments were carried out by putting 2.5 grams of $1-2 \mathrm{~mm}$ waste particles into drilled ( $0.5 \mathrm{~mm}$ pore size) polypropylene tube, following its immersion in the respective $100 \mathrm{~mL}$ solution, so that liquid to solid ratio was kept constant at 40 . The experiment addressing the effect of particle size was performed with $1-2,0.5-1$, and $0.25-0.5 \mathrm{~mm}$ waste particles. Since fine fraction $(0.25-0.5 \mathrm{~m})$ placement in the column tube was not feasible due to its removal through the holes, these experiments were performed by putting the waste materials into falcon tubes, keeping the parameter of liquid to solid ratio the same, that is, 40. The wastes were sterilized at $120^{\circ} \mathrm{C}$ within 15 minutes prior to use in the experiment, in order to eliminate potential microbial organisms and their influence on the waste dissolution and/or root exudates degradation (Banks et al. 1994). Organic root exudates solutions were sterilized by filtering with polyethersulfone (PES) $0.45 \mu \mathrm{m}$ filters. The tests were performed in acid ( $10 \%$ vol. $\mathrm{HNO}_{3}$ ) washed glass bottles ( $250 \mathrm{~mL}$ capacity), unless indicated otherwise. At the end of the experiments, the solutions were filtered using $0.45 \mu \mathrm{m}$ PTFE (Polytetrafluoroethylene) filters and acidified using $1 \%$ vol. of concentrated (65\%) $\mathrm{HNO}_{3}$ for elemental composition analysis.

\subsection{Analytical methods}

The elemental composition of the solutions resulting from each sampling point was measured by inductively coupled plasma atomic mass spectrometry (ICP-MS Nexion 300D Perkin Elmer). Detection limits were typically $0.1 \mu \mathrm{g} / \mathrm{L}$ and $1 \mu \mathrm{g} / \mathrm{L}$ for minor $(\mathrm{Cu}$, $\mathrm{Zn}, \mathrm{Pb}$ ) and major elements (Si, Fe), respectively. Relative standard deviation (RSD) of each measurement was below or equal to $2 \%$. For the measurements with RSD higher than $2 \%$, standard solution was analysed and sample analysis repeated in order to ensure the quality of data. Characterization of experimentally weathered slags was performed using binocular (ZEISS).

\section{3. RESULTS AND DISCUSSION}

\subsection{Effect of artificial root exudates concentration on the waste dissolution}

The quantity and type of soil organic matter may exhibit variations depending on local conditions (Kalbitz et al. 2000). Organic acids are inherently associated with rhizosphere soil fraction since their input is mainly given by root exudation and decaying biomass (Jones 1998, Wu et al. 2002). The importance of evaluating the impact of root exudates at different concentration ranges is relevant due to strong dependence in metal mobility along with changes of dissolved organic carbon content (Antoniadis and Alloway 2002; Pérez-Esteban 2017).

The results of the experiment addressing the impact of ARE concentration revealed that highly concentrated ARE solution (i.e., $600 \mathrm{mg} / \mathrm{L} \mathrm{DOC}$ ) increases the release of elements relative to experimental controls, that is, acidified demineralized water $(D W+A)$ and non-acidified demineralized water (DW) for all the analysed elements ( $\mathrm{Si}, \mathrm{Fe}, \mathrm{Cu}, \mathrm{Zn}$ and $\mathrm{Pb}$ ) and each studied waste (GS and LM) (Figure $1 \mathrm{~A}$ and B). However, the amounts of the elements in the leach solution varied from one ARE concentration to another (6-600 DOC). The notable quantitative difference for all the analysed elements' extraction was observed when ARE concentration increased from 60 to 600 , which stands to the conclusion that the impact of root exudates becomes quantitatively relevant at its high concentrations, while the release is more dependent on $\mathrm{pH}$ at its low concentrations.

Silicon and iron occur as the major chemical components of granulated slag (GS) (Potysz et al. 2016c) and these elements are incorporated in glass that is a volumetrically major component of GS (Potysz et al. 2016c). Therefore, the release of Si and Fe may be used for tracing the intensity of the weathering of GS. The 7 days long dissolution of GS in demineralized water (DW) resulted in the release of $\mathrm{Si}$ that reached $14.7 \pm 1.6 \mathrm{mg} / \mathrm{kg}$. At the same time, as much as $9.4 \pm 2.0 \mathrm{mg} / \mathrm{kg}$ of Cu was released, whereas the concentration achieved for other elements (i.e., Fe, $\mathrm{Zn}$ and $\mathrm{Pb}$ ) did not exceed $1.5 \mathrm{mg} / \mathrm{kg}$. Such behaviour of GS in DW indicates that this waste is weathering-sensitive and may dissolve even under exposure to low-aggressive, near-neutral (i.e., demineralized water) conditions. That is in accordance with numerous studies which demonstrated dissolution of glassy slags in demineralized and ultrapure water (e.g., Seignez et al. 2007; Yin et al. 2014; van Hullebusch et al. 2015; Potysz et al. 2016a).

The leaching of GS in acidified demineralized water $(D W+A)$ led to a higher element release as compared to this observed in DW. The amount of $\mathrm{Cu}$ after 7 days of experiment in DW+A medium reached $80.2 \pm 3.9 \mathrm{mg} / \mathrm{kg}$, which is 8.5 times higher as compared to DW (Figure 1). In addition, it is important to note that $\mathrm{Cu}$ dissolution under acidic conditions is slightly higher than $\mathrm{Si}$ $(59.9 \pm 1.2 \mathrm{mg} / \mathrm{kg})$. Such increase of Cu release may be due to 
Table 2. $\mathrm{pH}$ values recorded in the reactors

\begin{tabular}{|c|c|c|c|c|}
\hline & GS & & LM & \\
\hline TREATMENT & Average & RSD & Average & RSD \\
\hline DW FS 1-2 mm & 7.55 & \pm 0.04 & 5.29 & \pm 0.13 \\
\hline DW+A FS 1-2 mm & 5.55 & \pm 0.24 & 5.07 & \pm 0.10 \\
\hline ARE 6 FS $1-2 \mathrm{~mm}$ & 5.48 & \pm 0.02 & 5.07 & \pm 0.08 \\
\hline ARE 60 FS $1-2 \mathrm{~mm}$ & 5.47 & \pm 0.01 & 5.03 & \pm 0.08 \\
\hline ARE $600 \mathrm{FS} 1-2 \mathrm{~mm}$ & 5.22 & \pm 0.06 & 4.96 & \pm 0.04 \\
\hline ARE $60 \mathrm{FS} 1-2 \mathrm{~mm}$ & 6.12 & \pm 0.04 & 4.99 & \pm 0.03 \\
\hline ARE 60 FS $0.5-1 \mathrm{~mm}$ & 6.00 & \pm 0.04 & 4.95 & \pm 0.00 \\
\hline ARE 60 FS $0.25-0.5 \mathrm{~mm}$ & 5.95 & \pm 0.01 & 4.97 & \pm 0.03 \\
\hline
\end{tabular}

*RSD: Relative standard deviation, GS: granulated slag, LM: lead matte
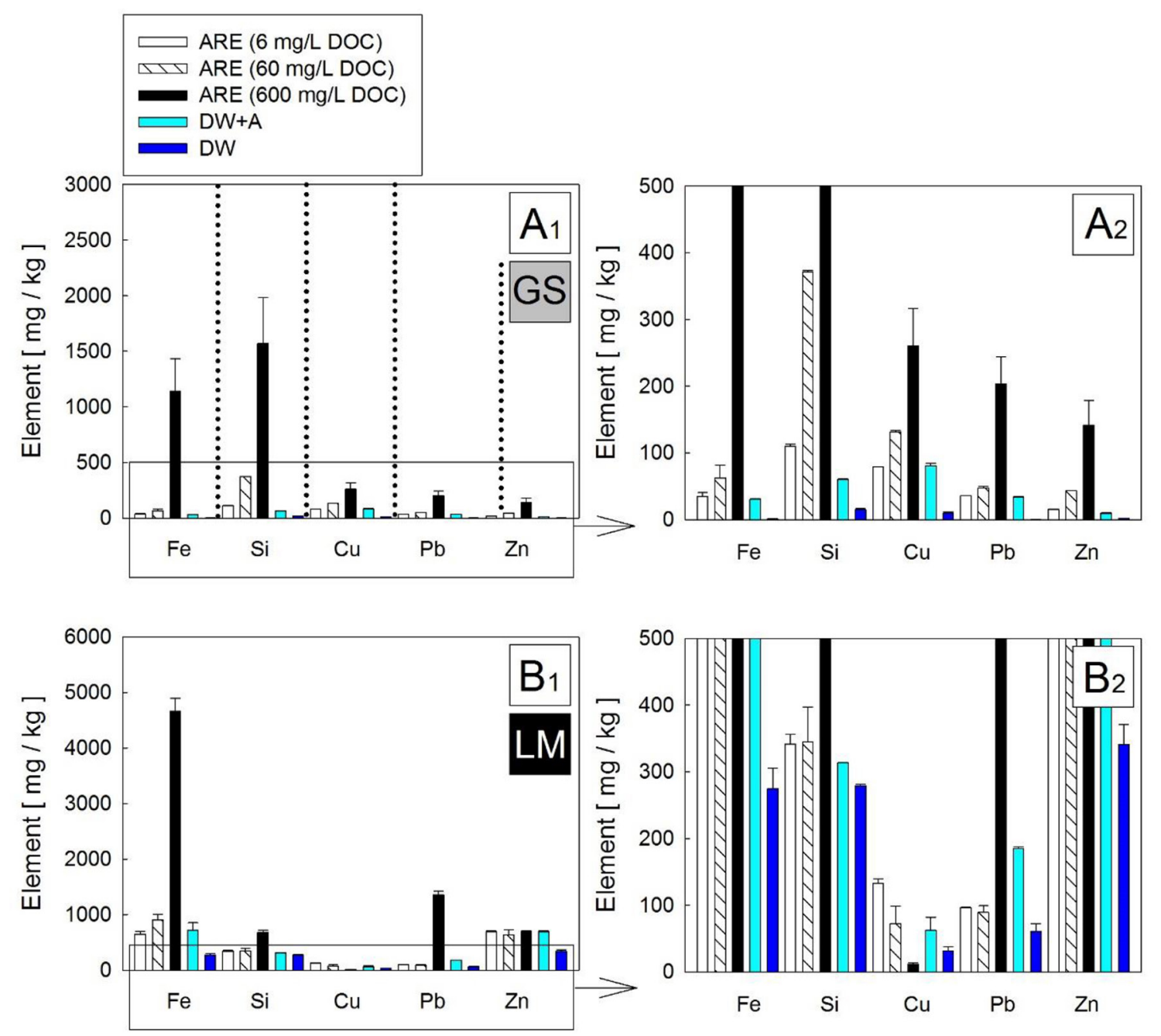

Figure 1. The release of elements from granulated slag (GS) and lead matte (LM) under exposure to different conditions:

$D W$ - demineralized water, DW+A-acidified demineralized water, ARE - artificial root exudates with different DOC content). 


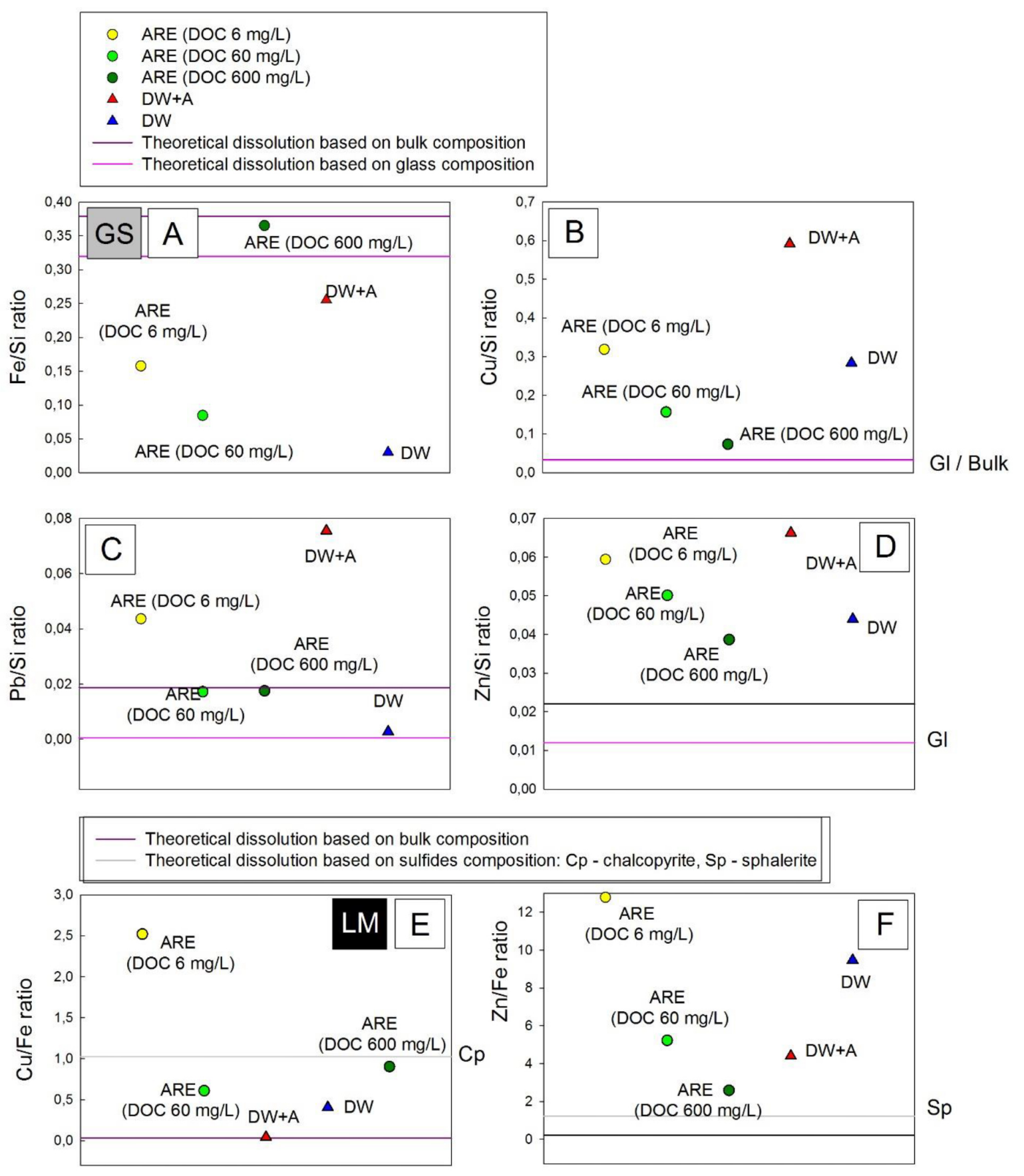

Figure 2. Theoretical dissolution of waste and phase based on molar ratios and dissolution received experimentally (Cp - chalcopyrite, Sp - sphalerite).

lower solution $\mathrm{pH}(5.55 \pm 0.24)$ compared to this recorded in DW $(7.55 \pm 0.04)$ (Table 2). It has already been demonstrated that low $\mathrm{pH}$ conditions are favourable for dissolution of Cu-carriers, that is, intermetallic droplets (Potysz et al. 2016c; Potysz et al. 2017). The release of major elements in DW+A was 4.1 (Si) and 34.2 (Fe) times higher as compared to DW control.
The 7 days long immersion of granulated slag (GS) in ARE solutions ranging in DOC content from 6 to $600 \mathrm{mg} / \mathrm{L}$ generally resulted in the highest release of $\mathrm{Si}(1571.3 \pm 410.0 \mathrm{mg} / \mathrm{kg})$ next to the other elements. The most plausible explanation is that $\mathrm{Si}$ is ubiquitous component of GS (Potysz et al. 2016c), rendering its accessibility by the leaching solution easy. However, despite its high quantita- 

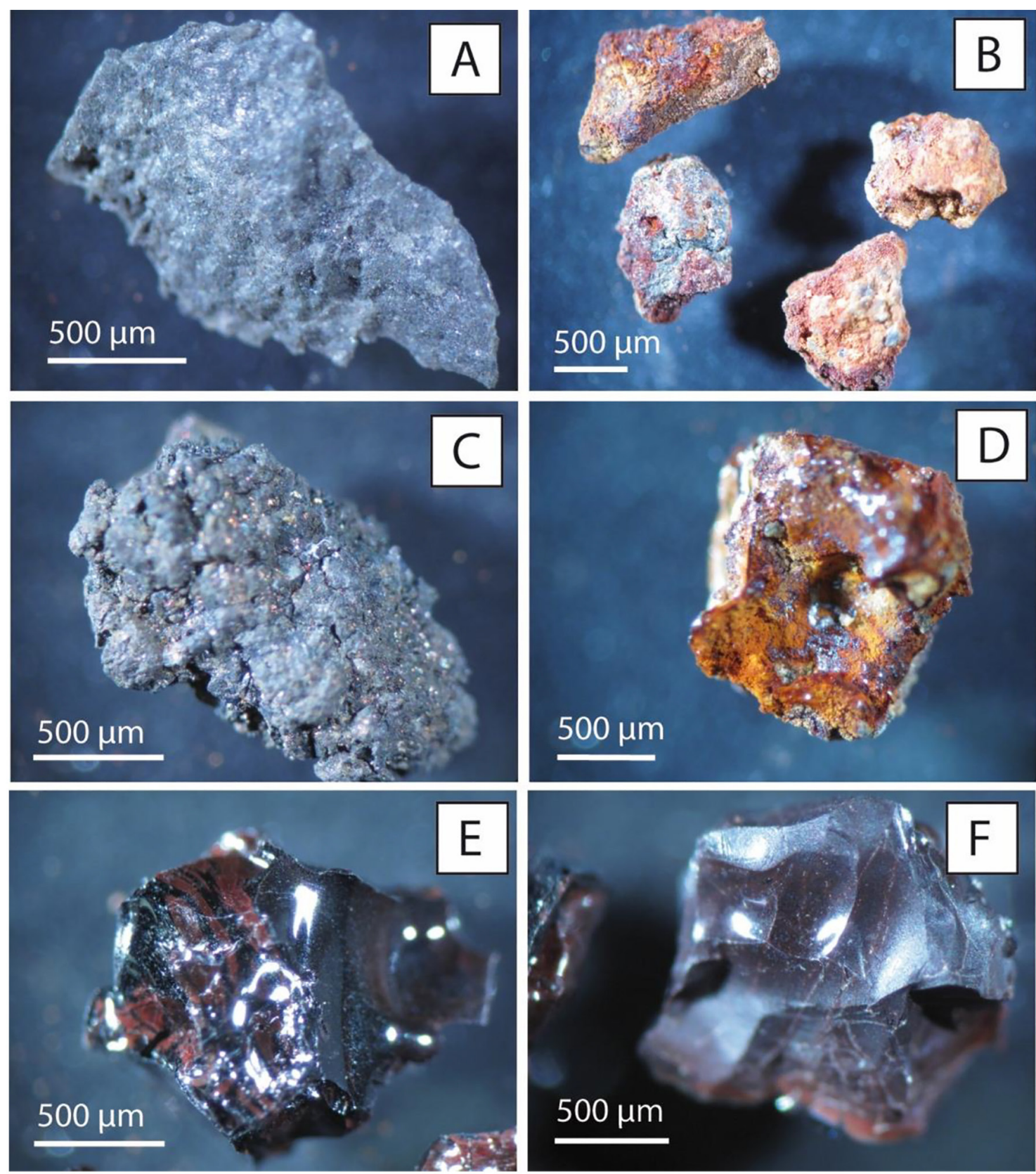

Figure 3. Microscopic images of the waste grains that were poorly and strongly weathered.

A - LM grain after 7 days long immersion in DW; B, C and D - LM after 7 days long immersion in ARE solution; $E$ - GS after 7 days long immersion in DW; $F-G S$ after 7 days long immersion in ARE.

tive release, it appears that other elements are also prone to release from GS incubated in the ARE solution (Figure $2 A-D$ ). The release of Fe in ARE 600 solution was particularly high and reached up to $1140.9 \pm 292.4 \mathrm{mg} / \mathrm{kg}$ (Figure $1 \mathrm{~A} 1$ ). The release of $\mathrm{Cu}$ and $\mathrm{Pb}$ from GS was comparable for DW+A, ARE 6 and ARE 60 treatments, which indicates that the element release under these conditions is governed by $\mathrm{pH}$ rather than the organics themselves. In contrast, $\mathrm{Zn}$ release from GS was sensitive to ARE concentration since the release was already 1.6 times higher in ARE 6 medium as compared to DW+A solution (Figure $1 \mathrm{~A} 2$ ).

Generally, the amount of Fe released from GS was lower as compared to Si for all studied conditions. According to the calculated molar ratios for theoretical and experimentally achieved dissolution (Figure 2), it appears that Fe is less easily released from the 
glass as compared to $\mathrm{Si}$ (Figure $2 \mathrm{~A}$ ). This indicates that Fe and Si are transferred from solid phase (i.e., glass) to liquid phase at different rates, probably due to the precipitation of secondary phases. In addition, the ratios calculated for $\mathrm{Cu}$ reveal that $\mathrm{Cu}$ is preferably released relative to $\mathrm{Si}$ for all the treatments performed (Figure $2 \mathrm{~B}$ ). That indicates that Cu present in the leachate is either easily leachable from the glass and/or comes from different phase, for example, intermetallic copper droplet. The release of Zn from the slag shows its easier leachability than Si despite the fact that $\mathrm{Zn}$ amount in the leachate is lower compared to Si (Figure $1 \mathrm{~A}_{2}$ ). Likewise, the $\mathrm{Pb}$ release shows similar behaviour. Therefore, it may be concluded that metallic elements being impurities of glass are easily leachable under the studied conditions.

Lead matte was found to be susceptible to dissolution under exposure to DW. Demineralized water treatment led to the release up to $340.7 \pm 29.9 \mathrm{mg} / \mathrm{kg}$ of $\mathrm{Zn}$ and slightly lower release of $\mathrm{Si}$ $(279.4 \pm 1.9 \mathrm{mg} / \mathrm{kg})$ and Fe $(274.2 \pm 30.7 \mathrm{mg} / \mathrm{kg})$. The high leachability of $Z n$ is surely due to the occurrence of volumetrically major $\mathrm{Zn}$-bearing phase, that is, marmatite. It has already been demonstrated that the dissolution of sulphidic mine wastes occurs at near-neutral conditions (Lindsay et al. 2009). Likewise, sphalerite owing composition similar to this of marmatite undergoes dissolution under acidic conditions (Domènech 2002; De Giudici et al. 2002). The acidified demineralized water enhanced the release of elements at least by factor $1.1(\mathrm{Si})$ up to $3.0(\mathrm{~Pb})$ relative to non-acidified demineralized water. Furthermore, the 7 days long leaching of LM with ARE (6 mg/L DOC) increased the release of the elements relative to acidified demineralized water even by factor $2.1(\mathrm{Cu})$, which suggests that even low quantities (i.e., $6 \mathrm{mg} / \mathrm{L} \mathrm{DOC)}$ of ARE may favour the dissolution of LM. Further increase of ARE concentration (i.e., $60 \mathrm{mg} / \mathrm{L} \mathrm{DOC}$ ) affected the release of most of the elements, beyond the $\mathrm{Zn}$ whose release was almost equal (from $636.0 \pm 91.0 \mathrm{mg} / \mathrm{kg}$ to $691.2 \pm 16.7 \mathrm{mg} / \mathrm{kg}$ ) for all ARE treatments. The release of $\mathrm{Zn}$ is surely the result of marmatite dissolution, which is the major phase component and main Zn carrier (Potysz et al. 2016c). However, as demonstrated in Figure $2 \mathrm{~F}$, it is clear that $\mathrm{Zn}$ is released more easily as compared to Fe for all $A R E, D W+A$ and DW treatments. It is also important to note that $\mathrm{Cu}$ content in an ARE 600 solution depleted by factor 6.3 relative to the ARE 60 . The most plausible explanation for such difference is possible occurrence of secondary precipitates in the studied system. Clearly demonstrated sulphides dissolution causes that sulphates content in the solution is expected to be high, favouring in turns precipitation of secondary sulphates (Bolan et al. 2014). The pictures taken on LM treated with ARE 60 solution clearly reveal frequently appearing precipitates having brownish and blueish colours, suggesting Fe and $\mathrm{Cu}$ precipitation (Figure 3). The release of $\mathrm{Cu}$ from $\mathrm{Cu}$-sulphides was facilitated only in the case of ARE 6 solution. However, taking into account the fact that an important quantity of Fe was surely released from marmatite; therefore, no reliable conclusion can be made on $\mathrm{Cu} / \mathrm{Fe}$ ratios.

\subsection{Effect of waste particle size on dissolution}

The disposal sites are characterized by the presence of wastes ranging in size from several centimetres up to several dozens of centimetres (e.g., Kierczak and Pietranik; Ettler et al. 2003, Potysz et al. 2016c). However, the fine particles may also occur as the result of physical weathering, that is, cracking, which in turns favours the waste dispersal to far located distances (Ettler 2016). Therefore, the study addressing the effect of waste particle size on dissolution is relevant for elucidating an environmental impact that these wastes may pose.

Laboratory simulation of metallurgical wastes weathering with ARE 60 solution revealed that the release of elements from this waste occur regardless of the used particle size and is not particle size dependent (Figures $4 \mathrm{~A}$ and $\mathrm{B}$ ). In the case of GS, the highest release was observed for $S i$ whose concentration ranged between $229.4 \pm 6.9 \mathrm{mg} / \mathrm{kg}$ and $234.2 \pm 2.0 \mathrm{mg} / \mathrm{kg}$ for fraction $0.25-0.5 \mathrm{~mm}$ and $0.5-1 \mathrm{~mm}$, respectively. This trend may again be justified by the easy access of weathering solution to the omnipresent phase component, that is, glass that results in a similar release for all the particles used. Furthermore, the release of $\mathrm{Fe}, \mathrm{Zn}$ and $\mathrm{Pb}$ did not show notable differences from one fraction size used to another (Figure 4 A). Over $90 \%$ of these elements are incorporated in glass structure; therefore, its dissolution resulted in similar quantities in each leachate. Only the copper release from granulated slag demonstrated fraction dependent trend such that decreased particle size from $1-2 \mathrm{~mm}$ to $0.25-0.5 \mathrm{~mm}$ led to the increased leaching of Cu by factor 1.5. That behaviour of Cu may also be explained by mineralogical composition of the slag, which contains intermetallic droplets as the main copper carriers distributed randomly, but frequently within the glass (Potysz et al. 2016c). Hence, decrease in the fraction size led to an easier access of the leaching solution to these Cu-droplets, which resulted in its dissolution and consequently higher release. Thus, it may be concluded that the reduction of particle size is a factor enhancing Cu extraction, when GS is being exposed to root exudates solution.

The release of the elements from lead matte waste has also not been affected by the fraction size in the range of $0.25-2 \mathrm{~mm}$ (Figure 4 B). An exception was observed for Fe whose release was 1.6 times higher when the fraction size was reduced from $1-2 \mathrm{~mm}$ to $0.25-0.5 \mathrm{~mm}$. General lack of dependence on the size particles is also due to the omnipresence of marmatite and the easy accessibility of leaching solution toward this Zn carrier.

\subsection{Long-term ( 7 weeks long) behaviour of the wastes}

The experiment addressing long-term behaviour of the slags exposed to DW and ARE conditions revealed continuous release of elements throughout the experiment until 35 days (5 weeks) of the experiment (Figure 5). Afterwards, steady state was achieved indicating very slow release of elements from LM and GS (Figure 5). At the end of the 7 weeks experiment, the element release 

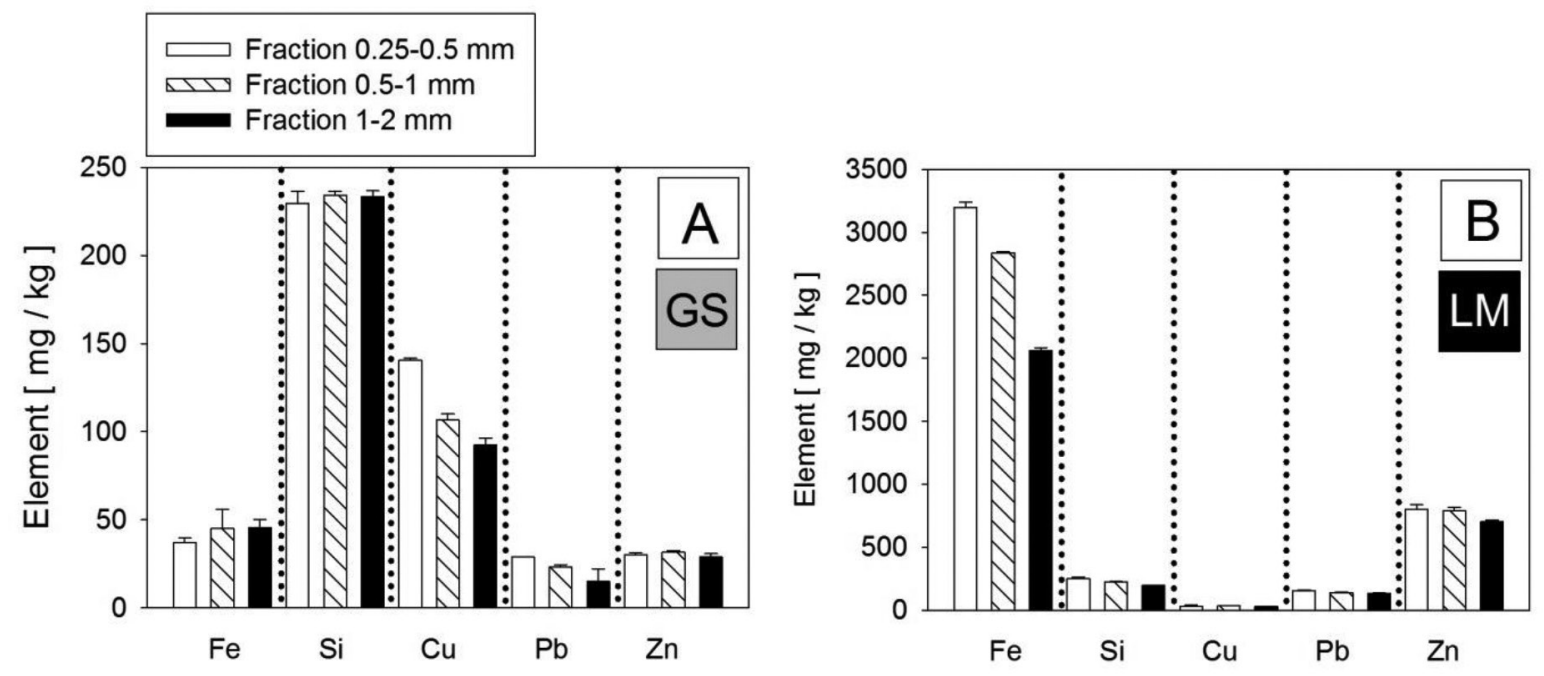

Figure 4. The effect of the particle size on elements release from granulated slag (A) and lead matte (B).

Table 3. The $\mathrm{pH}$ and relative values of the elements leached after the 7 weeks experiment with DW and ARE 60 solution.

\begin{tabular}{|c|c|c|c|c|}
\hline & GS & RSD & LM & RSD \\
\hline \multicolumn{5}{|l|}{ pH (7 weeks) } \\
\hline DW experiment & 7.70 & \pm 0.13 & 5.30 & \pm 0.12 \\
\hline ARE experiment & 5.38 & \pm 0.14 & 5.08 & \pm 0.01 \\
\hline \multicolumn{5}{|l|}{ DW experiment [\%] } \\
\hline $\mathbf{F e}$ & 0.001 & \pm 0.000 & 0.32 & \pm 0.03 \\
\hline Si & 0.025 & \pm 0.001 & 2.91 & \pm 0.05 \\
\hline $\mathrm{Cu}$ & 0.170 & \pm 0.064 & 4.83 & \pm 0.96 \\
\hline $\mathbf{P b}$ & 0.003 & \pm 0.002 & 3.71 & \pm 0.84 \\
\hline $\mathbf{Z n}$ & 0.036 & \pm 0.011 & 1.00 & \pm 0.06 \\
\hline \multicolumn{5}{|l|}{ ARE experiment [\%] } \\
\hline $\mathrm{Fe}$ & 0.60 & \pm 0.02 & 0.78 & \pm 0.08 \\
\hline Si & 0.99 & \pm 0.02 & 3.33 & \pm 0.40 \\
\hline $\mathrm{Cu}$ & 4.97 & \pm 0.07 & 1.39 & \pm 0.26 \\
\hline $\mathbf{P b}$ & 1.86 & \pm 0.05 & 17.80 & \pm 3.36 \\
\hline $\mathbf{Z n}$ & 2.19 & \pm 0.02 & 1.28 & \pm 0.12 \\
\hline
\end{tabular}

in ARE solution was enhanced relative to DW even by factor 4.8 $(\mathrm{Pb})$ and 675.1 (Fe) for GS and LM, respectively. When a quantitative comparison is being made on the two types of metallurgical wastes, it is seen that the release of Fe from LM immersed in DW was similar to the quantities of Fe released from GS exposed to ARE conditions (Figure 5). The effect of organics on the GS dissolution was clear since Si release to the ARE was 39.1 factor higher as compared to DW. Surprisingly, Cu release from LM was higher in DW as compared to ARE, which may suggest that precipitating mechanisms occurred in the ARE weathering system. Copper release from GS revealed similar trend to this observed for $\mathrm{Si}$ and Fe and it was higher in ARE solution than in DW (Figure 5). The release of $\mathrm{Pb}$ and $\mathrm{Zn}$ from $\mathrm{LM}$ was clearly improved by ARE in the case of both (i.e., GS and LM) wastes.

General susceptibility of the metallurgical wastes to dissolution should be estimated not only based on absolute amounts 

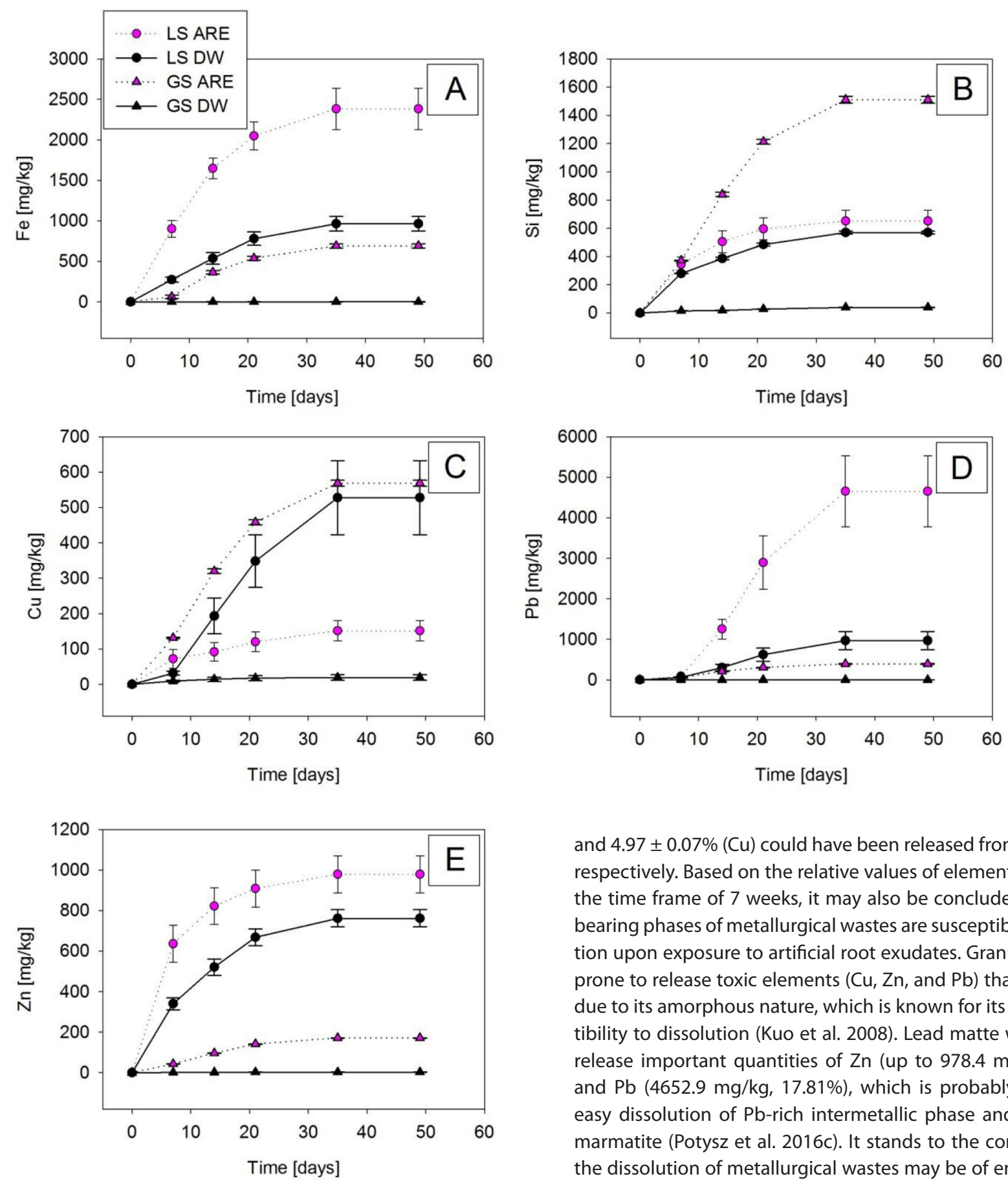

Figure 5. Cumulative release of the elements throughout the long-term experiment.

(i.e., $\mathrm{mg} / \mathrm{kg}$ ) of discharged metals, but relative values (i.e., metal discharge expressed in \%, Table 3) have to be also necessarily considered (Piatak et al. 2015; Potysz et al. 2015). The results of the 7 weeks experiment revealed that up to $17.80 \pm 3.36 \%(\mathrm{~Pb})$

and $4.97 \pm 0.07 \%(\mathrm{Cu})$ could have been released from LM and GS, respectively. Based on the relative values of elements released in the time frame of 7 weeks, it may also be concluded that metal bearing phases of metallurgical wastes are susceptible to dissolution upon exposure to artificial root exudates. Granulated slag is prone to release toxic elements $(\mathrm{Cu}, \mathrm{Zn}$, and $\mathrm{Pb})$ that is probably due to its amorphous nature, which is known for its high susceptibility to dissolution (Kuo et al. 2008). Lead matte was found to release important quantities of $\mathrm{Zn}$ (up to $978.4 \mathrm{mg} / \mathrm{kg}, 1.28 \%$ ) and $\mathrm{Pb}(4652.9 \mathrm{mg} / \mathrm{kg}, 17.81 \%)$, which is probably due to the easy dissolution of $\mathrm{Pb}$-rich intermetallic phase and $\mathrm{Zn}$ bearing marmatite (Potysz et al. 2016c). It stands to the conclusion that the dissolution of metallurgical wastes may be of environmental concern regarding relative (\%) and absolute amounts $(\mathrm{mg} / \mathrm{kg})$ of the elements that might be released to the environment when the waste is exposed to root exudates.

\subsection{Environmental considerations and perspectives}

Environmental inconveniences associated with disposal of metallurgical wastes enjoined necessity of handling these wastes in 


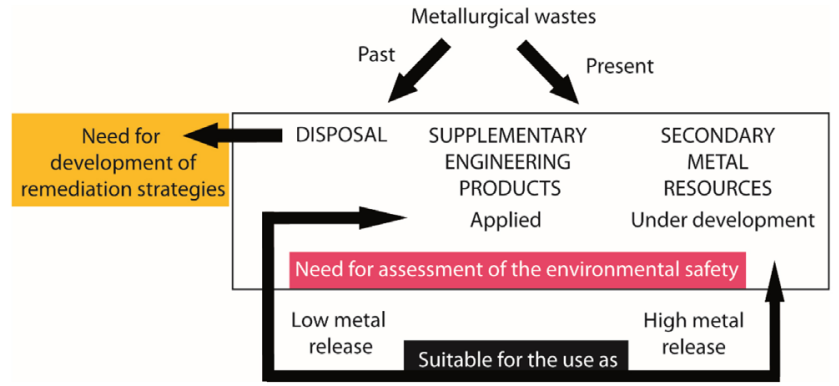

Figure 6. Sustainable evaluation of metallurgical waste and the choice for its suitable utilization.

environmental-safe manner. For this reason, metallurgical wastes are currently being evaluated either for its suitability to be used as supplementary engineering products or secondary metal resources (Figure 6). Waste reuse allows to avoid disposal and it is considered as suitable provided that the waste is stable in terms of toxic element release under defined conditions. The lack of stability of waste, that is, its susceptibility to release metals may also be considered advantageous and the wastes may then be suitable for the use as secondary metal resources (Figure 6). Environmentally safe management approaches are required not only for currently produced wastes, but also for historical wastes that are still disposed of. The removal of wastes from disposal sites would be an idealistic alternative to the current situation encountered at historical landfill sites. However, it has to be emphasized that such solution is a cost intensive operation; therefore, implementation of the well-suited remediation strategies may be a more realistic option. The effect of root exudates considered in this and the previous study (Potysz et al. 2017) shows that organic acid rich root exudates may affect the stability of metallurgical wastes. On the other hand, the presence of plants in a real disposal system makes their involvement in metal uptake highly possible
(Rascio and Navari-Izzo, 2011). Therefore, the main perspective stemming from this work is to simulate the waste weathering in the presence of natural root exudates and plants in order to estimate the amounts of metals that enter the soil environment and those entrapped by plants.

\section{CONCLUSIONS}

This study demonstrated that sulphide-rich lead matte and glassy copper slag are prone to weathering under exposure to nearneutral, acidic and organic-rich conditions. It has been found that $\mathrm{pH}$ is not the sole factor that governs element release from the wastes, because the presence of artificial root exudates additionally enhances the waste dissolution, especially upon its exposure to organic acids rich (600 mg/L DOC) ARE solution. The intermetallic phases hosting $\mathrm{Pb}$ and $\mathrm{Cu}$ as well as $\mathrm{Zn}$-bearing sulphide (i.e., marmatite) are prone to release metals. The waste particle size in the range of $0.25-0.5 \mathrm{~mm}$ to $1-2 \mathrm{~mm}$ was not found to have important effect on waste dissolution. Only the release of Cu from GS revealed particle size dependent trend that favoured $\mathrm{Cu}$ extraction when the slag particle was reduced. A long-term weathering of metallurgical wastes in the ARE solution revealed that metal bearing phases dissolve and release toxic elements in the quantities even up to $17.8 \%$.

\section{ACKNOWLEDGMENTS}

This work was financially supported by the Polish Ministry of Science and Higher Education project no. 0420/2288/17 to Anna Potysz. Anna Potysz gratefully acknowledges the Foundation for Polish Science (FNP) for START stipend 2017 for young researchers.

\section{REFERENCES}

[1] Anderson T.A., Guthrie E.A., Walton B.T. (1993). Bioremediation in the rhizosphere. Environmental Science and Technology., 1993, 27 (13), pp 2630-2636.

[2] Antoniadis V. \& Alloway B.J. (2002). The role of dissolved organic carbon in the mobility of $\mathrm{Cd}, \mathrm{Ni}$ and $\mathrm{Zn}$ in sewage sludge-amended soils. Environmental Pollution, 117(3), 515-521.

[3] Banks M.K., Waters C.Y., Schwab A.P. (1994). Influence of organic acids on leaching of heavy metals from contaminated mine tailings. Journal of Environmental Science \& Health Part A 29 (5), 1045-1056.

[4] Baudoin E., Benizri E., Guckert A. (2003). Impact of artificial root exudates on the bacterial community structure in bulk soil and maize rhizosphere. Soil Biology \& Biochemistry 35(9), 1183-1192.

[5] Bolan N., Kunhikrishnan A., Thangarajan R., Kumpiene J., Park J., Makino T., Kirkham M.B., Scheckel K. (2014). Remediation of heavy metal(oid)s contaminated soils - To mobilize or to immobilize? Journal of Hazardous Materials 266, 141-166.
[6] Bortey-Sam N., Nakayama S.M., Ikenaka Y., Akoto O., Baidoo E., Yohannes Y. B., Mizukawa H. \& Ishizuka M. (2015). Human health risks from metals and metalloid via consumption of food animals near gold mines in Tarkwa, Ghana: Estimation of the daily intakes and target hazard quotients (THQs). Ecotoxicology and environmental safety, 111, 160-167.

[7] De Giudici, G., Voltolini, M., \& Moret, M. (2002). Microscopic surface processes observed during the oxidative dissolution of sphalerite. European Journal of Mineralogy, 14(4), 757-762.

[8] Domènech C., De Pablo J., \& Ayora C. (2002). Oxidative dissolution of pyritic sludge from the Aznalcóllar mine (SW Spain). Chemical Geology, 190(1), 339-353.

[9] Ettler V. \& Johan Z. (2014). 12 years of leaching of contaminants from $\mathrm{Pb}$ smelter slags: geochemical/mineralogical controls and slag recycling potential. Applied Geochemistry 40, 97-103. 
[10] Ettler V., Johan Z., Kříbek B., Šebek O., Michaljevič M. (2009). Mineralogy and environmental stability of slags from Tsumeb smelter, Namibia. Applied Geochemistry 24 (1), 1-15.

[11] Ettler V., Komárková M., Jehlička J., Coufal P., Hradil D., Machovič V., Delorme F. (2004). Leaching of lead metallurgical slag in citric solutions- implications for disposal and weathering in soil environments. Chemosphere 57 (7), 567- 577.

[12] Ettler V., Mihaljevič M., Touray J.C., Piantone P. (2002). Leaching of polished sections: an integrated approach for studying the liberation of heavy metals from lead-zinc metallurgical slags. Bull. Soc. Geol. Fr. 2, 161-169.

[13] Ettler V., Piantone P., Touray J.C. (2003). Mineralogical control on inorganic contaminant mobility in leachate from lead-zinc metallurgical slag: experimental approach and long- term assessment". Mineralogical Magazine 67 (6), 1269-1283.

[14] Ettler V. (2016). Soil contamination near non-ferrous metal smelters: A review. Applied Geochemistry 64, 56-74.

[15] Gee C., Ramsey M.H., Maskall J., Thornton I. (1997). Mineralogy and weathering processes in historical smelting slags and their effect on the mobilisation of lead. Journal of Geochemical Exploration 58 (2-3), 249-257.

[16] Gonzalez C., Parra R., Klenovcanova A., Imris I., Sanchez M. (2005). Reduction of Chilean copper slags: a case of waste management project. Scandinavian Journal of Metallurgy 34 (2), 143-149.

[17] Hudson-Edwards K.A., Schell Ch., Macklin M.G. (1999). Mineralogy and geochemistry of alluvium contaminated by metal mining in the Rio Tinto area, southwest Spain. Applied Geochemistry 14 (8), 1015- 1030 .

[18] Jarošíková A., Ettler V., Mihaljevič M., Kříbek B., \& Mapani B. (2017). The $\mathrm{pH}$-dependent leaching behavior of slags from various stages of a copper smelting process: Environmental implications. Journal of environmental management, 187, 178-186.

[19] Jobbágy E. G. \& Jackson R. B. (2000). The vertical distribution of soil organic carbon and its relation to climate and vegetation. Ecological applications, 10(2), 423-436.

[20] Jones L.D. (1998). Organics acids in the rhizosphere-a critical review. Plant Soil 205 (1), 1849-1859.

[21] Kalbitz K., Solinger S., Park J.H., Michalzik B., \& Matzner E. (2000). Controls on the dynamics of dissolved organic matter in soils: a review. Soil science, 165(4), 277-304.

[22] Kay, B. D. (1998). Soil structure and organic carbon: a review. Soil processes and the carbon cycle, 198, 169-197.

[23] Kierczak J. \& Pietranik A. (2011). Mineralogy and composition of historical Cu slags from the Rudawy Janowickie Mountains, Southwestern Poland. Canadian Mineralogist 49 (5), 1281-1296.

[24] Kierczak J., Potysz A., Pietranik A., Tyszka R., Modelska M., Neel C., Ettler V., Mihaljevic M. (2013). Environmental impact of the historical Cu smelting in the Rudawy Janowickie Mountains (southwestern Poland). Journal of Geochemical Exploration 124, 183-194.

[25] Kuo Y., Wang J., Wang Ch., Tsai Ch. (2008). Effect of water quenching and $\mathrm{SiO} 2$ addition during vitrification of fly ash Part 1: On the crystalline characteristics of slags. Journal of Hazardous Materials 152 (3), 994-1001.

[26] Lindsay, M. B., Condon, P. D., Jambor, J. L., Lear, K. G., Blowes, D. W., \& Ptacek, C. J. (2009). Mineralogical, geochemical, and microbial investigation of a sulfide-rich tailings deposit characterized by neutral drainage. Applied Geochemistry, 24(12), 2212-2221.

[27] Lottermoser B.G. (2002). Mobilization of heavy metals from historical smelting slag dumps, north Queensland, Australia. Mineralogical Magazine 66 (4), 475-490.

[28] Lottermoser B.G. (2010). Mine Wastes: Characterization, Treatment and Environmental Impact: [2.1]: Early Historical Observations on
Sulfide Oxidation and Acid Mine Drainage, [2.7]: Acid generation prediction. Springer 3rd edition.

[29] Manz M. \& Castro L.J. (1997). The environmental hazard caused by smelter slags from the Sta. Maria de la Paz Mining District, Mexico. Environmental Pollution 98 (1), 7-13.

[30] Parsons M.B., Bird D.K., Einaudi M.T., Alpers Ch. N. (2001). Geochemical and mineralogical controls on trace element release from the Penn Mine base-metal slag dump, California". Applied Geochemistry $16(14), 1567-1593$.

[31] Pérez-Esteban J., Escolástico C., Masaguer A., Vargas C. \& Moliner A. (2014). Soluble organic carbon and $\mathrm{pH}$ of organic amendments affect metal mobility and chemical speciation in mine soils. Chemosphere, 103, 164-171.

[32] Piatak N.M., Parsons M.B., Seal R.R. (2015). Characteristics and Environmental Aspects of Slags: A review. Applied Geochemistry. 57, 236-266.

[33] Piatak N.M., Seal R.R., Hammarstrom J.M. (2004). Mineralogical and geochemical controls on the release of trace elements from slag produced by base- and precious-metal smelting at abandoned mine sites. Applied Geochemistry 19, 1039-1064.

[34] Piatak N.M. \& Seal R.R. (2010). Mineralogy and the release of elements from slag from the Hegeler Zinc smelter, Illinois (USA). Applied Geochemistry 25, 302-320.

[35] Potysz A., Grybos M., Kierczak J., Guibaud G., Lens P.N.L., van Hullebusch E.D. (2016a): Bacterially-mediated weathering of crystalline and amorphous Cu-slags. Applied Geochemistry 64, 92-106.

[36] Potysz A., Lens P.N.L., van de Vossenberg J., Rene E.R., Grybos M., Kierczak J., Guibaud G. \& van Hullebusch E.D. (2016b): Comparison of $\mathrm{Cu}, \mathrm{Zn}$ and Fe bioleaching from Cu-metallurgical slags in the presence of Pseudomonas fluorescens and Acidithiobacillus thiooxidans. Applied Geochemistry 68, 39-52.

[37] Potysz A., Kierczak J., Fuchs Y., Grybos M., Guibaud G., Lens P.N.L, van Hullebusch E.D. (2016c). Characterization and pH-dependent leaching behaviour of historical and modern copper slags, Journal of Geochemical Exploration 160, 1-15.

[38] Potysz A., van Hullebusch E.D., Kierczak J., Grybos M., Lens P.N.L., Guibaud, G. (2015). Copper Metallurgical Slags - Current Knowledge and Fate: A Review. Critical Reviews in Environmental Science and Technology 45 (22), 2424-2488.

[39] Potysz A., Grybos M., Kierczak J., Guibaud G., Fondaneche P., Lens P. N., \& van Hullebusch E.D. (2017). Metal mobilization from metallurgical wastes by soil organic acids. Chemosphere, 178, 197-211.

[40] Rascio N. \& Navari-Izzo F. (2011). Heavy metal hyperaccumulating plants: how and why do they do it? And what makes them so interesting? Plant science, 180(2), 169-181.

[41] Sandnes A., Eldhuset T.D., Wollebæk G. (2005). Organic acids in root exudates and soil solution of Norway spruce and silver birch. Soil Biology and Biochemistry 37(2), 259-269.

[42] Schmukat A., Duester L., Ecker D., Schmid H., Heil C., Heininger P., Ternes T.A. (2012). Leaching of metal(loid)s from a construction material: Influence of the particle size, specific surface area and ionic strength. Journal of Hazardous Materials (227), 257-264.

[43] Seignez N., Gauthier A., Bulteel D., Bautier M., Recourt P., Damidot $\mathrm{D.}$, Potdevin J.L. (2007). Effect of Pb-rich entities during alteration of a partially vitrified metallurgical waste. Journal of Hazardous Materials 149, 418-431.

[44] Tiller K.G. (1989). Heavy metals in soils and their environmental significance". Advances in Soil Science 9, 113142.

[45] Tyszka R., Kierczak J., Pietranik A., Ettler V., Mihaljevič M. (2014). Extensive weathering of zinc smelting slag in the heap in Upper Silesia (Poland): potential environmental risks posed by mechanical disturbance of slag deposits". Applied Geochemistry 40, 70-81. 
[46] van Hullebusch E.D., Yin N-H., Seignez N., Labanowski J., Gauthier A., Lens P.N.L., Avril C., Sivry Y. (2015): Bio-alteration of metallurgical wastes by Pseudomonas aeruginosa in a semi flow-through reactor. Journal of Environmental Management 147, 297-305.

[47] Wu J., West L.J., Stewart D.I. (2002). Effect of humic substances on Cu (II) solubility in kaolin-sand soil. J. Hazard. Mater. 94 (3), 223-238.
[48] Yin N.-H., Sivry Y., Avril C., Borensztajn S., Labanowski J., Malavergne V., Lens P.N.L., Rossano S., van Hullebusch E.D. (2014). Bioweathering of lead blast furnace (LBF) metallurgical slags by Pseudomonas aeruginosa, International Biodeterioration \& Biodegradation $86,372-381$. 